\title{
Pengaruh Pengaturan Komposisi Media Tanam Organik Terhadap Pertumbuhan Dan Hasil Tanaman Ubi Jalar ( Ipomoea batatas L.) Dengan Sistem Tabilampot
}

\author{
Mohamad Ghufron Mardiyanto ${ }^{1}$, Siti Muslikah¹, Nurhidayati ${ }^{1 *}$ \\ ${ }^{1}$ Departemen Agroteknologi, Fakultas Pertanian, Universitas Islam Malang, \\ Jl. MT. Haryono No. 193 Malang 65144, Jawa Timur, Indonesia \\ Email korespondensi : nurhidayati@unisma.ac.id
}

\begin{abstract}
Abstrak
Ubi jalar merupakan sumber karbohidrat alternatif yang memiliki kandungan gizi yang tinggi. Pengembangan cara budidaya ubi jalar perlu dilakukan untuk mengatasi semakin menyempitnya luas lahan pertanian produktif akibat konversi lahan. Penelitian ini bertujuan untuk menguji pengaruh perbedaan komposisi media tanam terhadap pertumbuhan, hasil, dan kualitas tanaman ubi jalar. Penelitian ini merupakan percobaan pot menggunakan Rancangan Acak Kelompok (RAK) dengan 7 perlakuan dan 5 kali ulangan. Macam perlakuan yang diujikan adalah P0: Tanah 100\% + pupuk anorganik; P1: Tanah 50\% + Kotoran Sapi 50\%; P2: Tanah 50\% + Vermikompos 50\%; P3: Tanah 50\% + Biochar Sekam Padi 25\%, Kotoran Sapi 25\%, P4: Tanah 50\% + Biochar Sekam Padi 25\% + Vermikompos 25\%, P5: Tanah 50\% + Cocopeat 25\% + Kotoran Sapi 25\%, P6: Tanah $50 \%+$ Cocopeat $25 \%$ + Vermikompos $25 \%$. Hasil penelitian menunjukkan bahwa macam komposisi media tanam berpengaruh nyata terhadap pertumbuhan dan hasil tanaman. Hasil analisis statistik menunjukkan bahwa perlakuan P4 dan P6 memberikan pertumbuhan tertinggi, sedangkan hasil bobot segar umbi per pot yang tinggi terdapat pada perlakuan P1, P2, P3, dan P4 yaitu masing-masing sebesar 165,59 g, 143,38 g, $171,56 \mathrm{~g}$, dan $144,80 \mathrm{~g}$. Jumlah umbi tertinggi terdapat pada perlakuan P6 yaitu sebesar 7,66 umbi. Hasil bahan kering tertinggi juga ditemukan pada perlakuan P1, P2, P3, dan P4 yaitu masing-masing sebesar $59,91 \mathrm{~g}, 51,73 \mathrm{~g}, 59,02 \mathrm{~g}$, dan 48,59 g. Berdasarkan hasil penelitian ini dapat direkomendasikan bahwa budidaya tanaman ubi jalar dalam pot dapat dilakukan dengan menggunakan media tanam yang porus dalam suatu kontainer yang cukup memadai serta tersedia unsur hara yang seimbang untuk perkembangan umbi tanaman.
\end{abstract}

Kata kunci:Vermikompos, komposisi media tanam, Ubi jalar, Hasil, Kualitas

\section{Abstract}

Sweet potatoes are an alternative source of carbohydrates that have high nutritional content. Development of sweet potato cultivation methods needs to be done to overcome the decrease of productive agricultural land due to land conversion. This study aimed to test the effect of differences in the composition of the growing media on the growth, yield, and quality of sweet potato. This study was a pot experiment using a Randomized Block Design (RBD) with 7 treatments and 5 replications. The types of treatments tested were P0: $100 \%$ soil + inorganic fertilizer; P1: $50 \%$ soil + 50\% cow manure; P2: soil $50 \%+$ vermicompost 50\%; P3: soil 50\% + biochar rice husk 25\%, cow manure $25 \%$, P4: soil $50 \%$ + biochar rice husk $25 \%$ + vermicompost $25 \%$, P5: soil $50 \%+$ cocopeat $25 \%+$ cow manure $25 \%$, P6: soil $50 \%$ + cocopeat $25 \%$ + vermicompost $25 \%$. The research results showed that the composition of the growing medium significantly affected plant growth and 
yield. The results of the statistical analysis showed that the treatments of P4 and P6 gave the highest growth, while the high yield of fresh weight of tubers per pot were found in the treatments P1, P2, P3, and P4 by $165.59 \mathrm{~g}, 143.38 \mathrm{~g}, 171.56 \mathrm{~g}$, and $144.80 \mathrm{~g}$, respectively. The highest number of tubers was found in treatment P6 by 7.66 tubers. The highest yield of dry matter was also found in treatments P1, P2, P3, and P4 by $59.91 \mathrm{~g}$, $51.73 \mathrm{~g}, 59.02 \mathrm{~g}$, and $48.59 \mathrm{~g}$, respectively. Based on the research results, it can be recommended that the cultivation of sweet potato plants in pots can be carried out using porous growing media in a container that is sufficient and available balanced nutrients for the development of plant tubers.

Keywords: Vermicompost, composition of growing media, Sweet Potatoes, Yield, Quality

\section{Pendahuluan}

Ubi jalar (Ipomoea batatas) adalah salah satu tanaman pangan penting di dunia, setelah gandum, beras, jagung, kentang, dan barley. Di Indonesia Ubi jalar cukup melimpah, namun potensi ubi jalar untuk menjamin ketahanan pangan masih belum optimal karena penggunaannya sering terbatas pada makanan pengganti. Menurut hasil survey Badan Pusat Statistik (2015), produksi ubi jalar di Indonesia tahun 2015 sebesar 2,26 juta ton dan sebagian besar produksi tersebut $89 \%$ digunakan sebagai bahan pangan. Salah satu bentuk olahan ubi jalar yang cukup potensial dalam kegiatan industri pangan adalah tepung ubi jalar. Tepung ubi jalar dapat menjadi pilihan yang tepat untuk pemenuhan kebutuhan bahan baku berbasis lokal.

Ubi jalar termasuk kelompok ubi-ubian yang memiliki kandungan gizi tinggi. Menurut USDA (United States Department of Agriculture) Agricultural Research Service bahwa dalam $100 \mathrm{~g}$ ubi jalar mengandung kalori (86 kkal), karbohidrat $(20,1 \mathrm{~g})$, gula (4.2 $\mathrm{g})$, protein $(1,6 \mathrm{~g})$, serat $(1,7 \mathrm{~g})$, vitamin $\mathrm{A}(709 \mu \mathrm{g})$, vitamin $\mathrm{C}(2,4 \mathrm{mg})$, vitamin $\mathrm{E}(0.26$ $\mathrm{mg}$ ), dan vitamin B5 (0,8 mg) (Anonimous, 2019).

Pengembangan cara menanam budidaya ubi jalar perlu dilakukan untuk mengatasi semakin menyempitnya luas lahan pertanian produktif akibat konversi lahan. Sistem penanaman ubi jalar dalam pot masih jarang dilakukan oleh petani dan masyarakat pemerhati pertanian. Penanaman ubi-ubian dalam pot (Tabilampot) merupakan kegiatan tanam menanam pada lahan yang terbatas. Metode ini juga memberikan manfaat dalam upaya pengembangan produk pangan non beras sebagai sumber karbohidrat alternative bagi masyarakat di wilayah perkotaan, sehingga diharapkan kebutuhan ubi jalar nasional dapat semakin terpenuhi. 
Penanaman ubi jalar dalam pot membutuhkan karakteristik media yang khusus antara lain, harus porus, tidak padat, aerasi baik, mampu menahan air dan unsur hara dengan baik, kondisi ini dibutuhkan untuk perkembangan dan pembesaran umbi. Oleh karena itu perlu dilakukan pengaturan komposisi media tanam yang dapat menghasilkan umbi secara optimal. Pada penelitian ini menggunakan komposisi media tanam campuran yang terdiri cocopeat dan biochar serta kotoran sapi dan vermikompos sebagai nutrisinya.

Pupuk kandang dari kotoran sapi memiliki kandungan serat yang tinggi. Serat atau selulosa merupakan senyawa rantai karbon yang akan mengalami proses dekomposisi lebih lanjut. Proses dekomposisi senyawa tersebut memerlukan unsur $\mathrm{N}$ yang terdapat dalam kotoran. Sehingga kotoran sapi tidak dianjurkan untuk diaplikasikan dalam bentuk segar, perlu pematangan atau pengomposan terlebih dahulu (Risnandar, 2012). Kotoran ternak sapi merupakan pupuk dingin, yang memiliki kadar hara kotoran padat (feses) yaitu Nitrogen $=0,40 \%$, Fosfor $=0,20 \%$, Kalium $=0,10 \%$, dan Air $85 \%$ sedangkan urine memiliki kadar hara yaitu Nitrogen $=1,00 \%$, Fosfor $=0,50 \%$, Kalium $=1,50 \%$, dan Air $92 \%$ (Lingga, 2001).

Vermikompos adalah pupuk organik yang memiliki unsur hara tinggi karena dalam vermikompos mengandung kotoran cacing. Keunggulan vermikompos adalah menyediakan $\mathrm{N}, \mathrm{P}, \mathrm{K}, \mathrm{Ca}$ dan $\mathrm{Mg}$ yang tersedia dalam jumlah yang seimbang dan meningkatkan kandungan bahan organik, meningkatkan kemampuan tanah, menyediakan hormon pertumbuhan tanaman serta sebagai penyangga pengaruh negatif (Lazcano dan Dominguez, 2011). Selain itu aplikasi vermikompos mampu meningkatkan kualitas tanaman kubis (Nurhidayati et al., 2016), meningkatkan pertumbuhan dan hasil tanaman brokoli (Nurhidayati dkk., 2017a) serta memberikan efek residu positif pada tanaman berikutnya (Nurhidayati et al., 2017b; Nurhidayati et al., 2018). Penelitian ini bertujuan untuk menguji pengaruh perbedaan komposisi media tanam terhadap pertumbuhan, hasil dan kualitas tanaman ubi jalar.

\section{Bahan dan Metode}

Penelitian ini merupakan percobaan pot yang ditempatkan di lahan percobaan Fakultas Pertanian Universitas Islam Malang, pada ketinggian tempat $540 \mathrm{~m}$. Penelitian ini dilaksanakan pada bulan September 2019 - Maret 2020. Pembuatan vermikompos dilakukan di Laboratorium Kompos Fakultas Pertanian Unisma. 
Peralatan yang digunakan adalah kotak vermikomposting, pot plastik, dan alat-alat analisis tanaman di laboratorium. Bahan-bahan yang digunakan dalam penelitian adalah tanah, cocopeat, biochar sekam padi, cacing (Lumbricus rubellus), kotoran sapi, serasah daun, sisa sayuran pasar, sisa media jamur, tepung cangkang telur, tepung tulang ikan, daun paitan dan bibit stek ubi jalar varietas Papua solossa.

Penelitian ini merupakan percobaan pot menggunakan Rancangan Acak Kelompok (RAK). Macam perlakuan yang diujikan adalah P0: Tanah 100\% + pupuk anorganik; P1: Tanah 50\% + Kotoran Sapi 50\%; P2: Tanah 50\% + Vermikompos 50\%; P3: Tanah 50\% + Biochar Sekam Padi 25\%, Kotoran Sapi 25\%; P4: Tanah 50\% + Biochar Sekam Padi 25\% + Vermikompos 25\%; P5: Tanah 50\% + Cocopeat 25\% + Kotoran Sapi 25\%; P6: Tanah $50 \%+$ Cocopeat $25 \%$ + Vermikompos $25 \%$. Tiap perlakuan diulang lima kali dan masingmasing ulangan menggunakan tiga pot yang berisi 2 tanaman.

Pembuatan vermikompos dilaksanakan di laboratorium kompos, pembuatan vermikompos menggunakan kotak kayu berukuran $80 \times 120 \mathrm{~cm}$ dan tinggi $30 \mathrm{~cm}$. Tahapan pembuatan vermikompos meliputi : persiapan residu, pencampuran media, inokulasi cacing Lumbricus rubellus, dan pemeliharaan media cacing pada kondisi kadar air $80 \%$. Proses pembuatan vermikompos terdiri dari dua proses yaitu vermicomposting selama 1 bulan dan composting selama 2 minggu. Aplikasi vermikompos pada media tanam sesuai dengan komposisi yang ditetapkan sesuai perlakuan dengan bobot total media sebesar $6 \mathrm{~kg}$ per pot. Ubi jalar ditanam langsung pada media tanam dalam pot dengan posisi ditidurkan. Setiap pot ditanam 2 stek ubi jalar. Pemanenan dilakukan pada umur 5,5 bulan setelah tanam.

Variabel yang diamati meliputi variabel pertumbuhan (panjang sulur, jumlah daun, dan jumlah cabang) dan variabel hasil (berat segar dan kering total brangkasan, jumlah umbi per pot, bobot segar umbi per pot, dan bobot bahan kering umbi). Penelitian ini menggunakan Rancangan Acak Kelompok (RAK) dan diuji lanjut menggunakan Uji BNJ dengan taraf $5 \%$.

\section{Hasil dan Pembahasan}

\section{Pengaruh Pemberian Macam Komposisi Media Tanam Organik Terhadap}

\section{Pertumbuhan Tanaman Ubi Jalar}

Hasil analisis ragam memperlihatkan bahwa macam komposisi media tanam ubi jalar dalam pot memberikan pengaruh nyata pada semua variabel yang diamati, yang 
meliputi panjang sulur, jumlah daun, jumlah cabang. Hasil uji BNJ 5\% menunjukkan bahwa perlakuan P2 (Tanah 50\% + Vermikompos 50\%), P4 (Tanah 50\% + Biochar Sekam Padi 25\% + Vermikompos 25\%) dan P6 (Tanah 50\% + Cocopeat 25\% + Vermikompos $25 \%$ ) cenderung memberikan pertumbuhan yang lebih tinggi, walaupun dalam beberapa pengamatan tidak berbeda nyata dengan beberapa perlakuan yang lain. Perlakuan ini menggunakan bahan media biochar sekam padi yang memiliki kandungan karbon tinggi. Biochar dihasilkan dari proses pemanasan dalam wadah dengan sedikit atau tanpa udara yang disebut dengan proses pirolisis (Harsono et al., 2013). Biochar digunakan sebagai bahan pembenah tanah untuk memperbaiki sifat-sifat tanah seperti sifat fisik, kimia dan biologi tanah sehingga kualitas tanah meningkat (Gani, 2009). Pada perlakuan ini menggunakan pupuk organik vermikompos. Vermikompos adalah hasil dekomposisi lebih lanjut dari pupuk kompos oleh cacing tanah yang mempunyai bentuk dan kandungan hara lebih baik untuk tanaman (Hadiwiyono dan Dewi, 2000). Beberapa keunggulan vermikompos adalah menyediakan hara $\mathrm{N}, \mathrm{P}, \mathrm{K}, \mathrm{Ca}, \mathrm{Mg}$ dalam jumlah yang seimbang dan tersedia (Sutanto, 2002).

Fatahillah (2017) menambahkan bahwa penggunaan vermikompos memberikan pengaruh positif terhadap pertumbuhan vegetatif pada cabai rawit (Capsicum frutescens L.). Aplikasi vermikompos pada tanaman sayuran juga memperlihatkan pengaruh signifikan dalam meningkatkan pertumbuhan tanaman brokoli dibandingkan kontrol (Nurhidayati et al., 2017a; Nurhidayati et al., 2017b). Aplikasi vermikompos dengan dosis 8 ton/ha dapat meningkatkan pertumbuhan tinggi tanaman, diameter batang, luas daun, indeks luas daun, laju pertumbuhan tanaman, laju asimilasi bersih, berat kering akar dan tajuk tanaman kacang kedelai kuning Varietas Anjasmoro (Saputro, 2012). Widjianto et al (2008) melaporkan bahwa aplikasi vermikompos dengan dosis 10 ton/ha juga terbukti mampu menigkatkan berat umbi dan mampu menurunkan presentase jumlah umbi yang yang berukuran kecil serta memberikan hasil panen tertinggi. Kombinasi vermikompos dengan pupuk anorganik juga terbukti menigkatkan diameter batang dan bobot 100 biji jagung (Nasution et al., 2014). 
Tabel 1. Pengaruh Pemberian Macam Komposisi Media Tanam Organik Terhadap Pertumbuhan Tanaman Ubi Jalar pada umur 56 HST.

\begin{tabular}{cccc}
\hline Perlakuan & Panjang sulur $(\mathrm{cm})$ & Jumlah daun (helai) & Jumlah cabang \\
\hline P0 & $103,3 \mathrm{~b}$ & $29,57 \mathrm{ab}$ & $2,73 \mathrm{ab}$ \\
P1 & $66,67 \mathrm{ab}$ & $27,50 \mathrm{ab}$ & $2,33 \mathrm{a}$ \\
P2 & $103,29 \mathrm{~b}$ & $39,80 \mathrm{~b}$ & $3,57 \mathrm{ab}$ \\
P3 & $65,75 \mathrm{a}$ & $23,90 \mathrm{ab}$ & $2,70 \mathrm{ab}$ \\
P4 & $96,17 \mathrm{ab}$ & $43,53 \mathrm{~b}$ & $4,40 \mathrm{~b}$ \\
P5 & $67,98 \mathrm{ab}$ & $19,83 \mathrm{a}$ & $2,13 \mathrm{a}$ \\
P6 & $76,48 \mathrm{ab}$ & $34,33 \mathrm{ab}$ & $3,87 \mathrm{ab}$ \\
\hline BNJ 5\% & 37,21 & 17,41 & 1,98
\end{tabular}

Keterangan : Angka yang diikuti oleh huruf yang sama pada kolom yang sama menunjukkan hasil yang tidak berbeda nyata.

\section{Pengaruh Pemberian Macam Komposisi Media Tanam Organik Terhadap Hasil Tanaman Ubi Jalar}

Hasil analisis ragam memperlihatkan bahwa macam komposisi media tanam ubi jalar dalam pot memberikan pengaruh nyata pada semua variabel yang diamati, yang meliputi bobot brangkasan (Tabel 2), jumlah umbi per pot (Tabel 3), bobot segar umbi (Tabel 4), dan bobot bahan kering umbi (Tabel 5).

Tabel 2. Pengaruh Pemberian Macam Komposisi Media Tanam Organik Terhadap Bobot Brangkasan Tanaman Ubi Jalar.

\begin{tabular}{lcc}
\hline & Berlakuan & BK Total Brangkasan $(\mathrm{g})$ \\
\hline P0 & $855,68 \mathrm{ab}$ & $134,15 \mathrm{~b}$ \\
P1 & $1083,86 \mathrm{~b}$ & $131,60 \mathrm{~b}$ \\
P2 & $1032,30 \mathrm{~b}$ & $123,19 \mathrm{~b}$ \\
P3 & $739,40 \mathrm{a}$ & $88,12 \mathrm{a}$ \\
P4 & $908,68 \mathrm{ab}$ & $106,56 \mathrm{ab}$ \\
P5 & $772,98 \mathrm{a}$ & $95,91 \mathrm{a}$ \\
P6 & $748,56 \mathrm{a}$ & $88,17 \mathrm{a}$ \\
\hline BNJ 5\% & 225,11 & 26,19 \\
\hline \multicolumn{2}{r}{ Keterangan : Angka yang diikuti oleh huruf yang sama pada kolom yang sama menunjukkan hasil } \\
\multicolumn{2}{c}{}
\end{tabular}


Tabel 3. Pengaruh Pemberian Macam Komposisi Media Tanam Organik Terhadap Jumlah Umbi Tanaman Ubi Jalar.

\begin{tabular}{cc}
\hline Perlakuan & Jumlah Umbi per pot \\
\hline P0 & $3,57 \mathrm{a}$ \\
P1 & $7,41 \mathrm{ef}$ \\
P2 & $6,23 \mathrm{de}$ \\
P3 & $5,02 \mathrm{bc}$ \\
P4 & $3,92 \mathrm{ab}$ \\
P5 & $5,63 \mathrm{~cd}$ \\
P6 & $7,66 \mathrm{f}$ \\
\hline BNJ 5\% & 1,29 \\
\hline
\end{tabular}

Keterangan : Angka yang diikuti oleh huruf yang sama pada kolom menunjukkan hasil yang tidak berbeda nyata.

Tabel 4. Pengaruh Pemberian Macam Komposisi Media Tanam Organik Terhadap Bobot Segar Umbi Tanaman Ubi Jalar.

\begin{tabular}{ccc}
\hline Perlakuan & Berat segar umbi per pot $(\mathrm{g})$ & Bobot segar per umbi $(\mathrm{g})$ \\
\hline P0 & $62,87 \mathrm{a}$ & $18,44 \mathrm{ab}$ \\
P1 & $165,59 \mathrm{~d}$ & $25,83 \mathrm{bc}$ \\
P2 & $143,38 \mathrm{~cd}$ & $27,22 \mathrm{~cd}$ \\
P3 & $171,56 \mathrm{~d}$ & $34,69 \mathrm{de}$ \\
P4 & $144,80 \mathrm{~cd}$ & $38,60 \mathrm{e}$ \\
P5 & $99,24 \mathrm{ab}$ & $18,79 \mathrm{ab}$ \\
P6 & $110,08 \mathrm{bc}$ & $15,93 \mathrm{a}$ \\
\hline BNJ 5 & 36,74 & 7,52
\end{tabular}

Keterangan : Angka yang diikuti oleh huruf yang sama pada kolom menunjukkan hasil yang tidak berbeda nyata.

Secara umum memperlihatkan bahwa perlakuan P1 (Tanah 50\% + Kotoran Sapi 50\%), P2 (Tanah 50\% + Vermikompos 50\%), P3 (Tanah 50\% + Biochar Sekam Padi 25\% + Kotoran Sapi 25\%) dan P4 (Tanah 50\% + Biochar Sekam Padi 25\% + Vermikompos 25\%) memberikan hasil yang tinggi. Perlakuan P6 (Tanah 50\% + Cocopeat 25\%+ Vermikompos $25 \%$ ) memberikan hasil yang lebih rendah sekalipun pada peubah tumbuh memberikan pertumbuhan yang tinggi. Hal ini kemungkinan disebabkan oleh pertumbuhan vegetatifnya yang terlalu besar sehingga alokasi fotosintat pada pembesaran umbi berkurang. Menurut Sato dan Mori (2001) defoliasi ditujukan pada daun pucuk dengan sasaran asimilat akan dapat lebih teralokasikan pada organ penyimpan, yaitu umbi yang 
pada akhirnya akan dapat berpengaruh pada hasil akhir tanaman sehingga diharapkan dapat meningkatkan produktivitas ubi jalar.

Tabel 5. Pengaruh Pemberian Macam Komposisi Media Tanam Organik Terhadap Bobot Bahan Kering Umbi Tanaman Ubi Jalar.

\begin{tabular}{ccc}
\hline Perlakuan & $\begin{array}{c}\text { Bobot Bahan kering } \\
\text { umbi per pot }(\mathrm{g})\end{array}$ & $\begin{array}{c}\text { Bobot bahan kering } \\
\text { per umbi }(\mathrm{g})\end{array}$ \\
\hline P0 & $25,10 \mathrm{a}$ & $7,10 \mathrm{ab}$ \\
P1 & $59,91 \mathrm{c}$ & $8,11 \mathrm{~b}$ \\
P2 & $51,73 \mathrm{c}$ & $8,32 \mathrm{~b}$ \\
P3 & $59,02 \mathrm{c}$ & $12,00 \mathrm{c}$ \\
P4 & $48,59 \mathrm{bc}$ & $12,59 \mathrm{c}$ \\
P5 & $35,94 \mathrm{ab}$ & $6,64 \mathrm{ab}$ \\
P6 & $37,04 \mathrm{ab}$ & $4,88 \mathrm{a}$ \\
\hline BNJ 5\% & 13,01 & 3,23
\end{tabular}

Keterangan : Angka yang diikuti oleh huruf yang sama pada kolom menunjukkan hasil yang tidak berbeda nyata.

Hasil yang tinggi pada empat perlakuan yaitu perlakuan P3 (Tanah 50\% + Biochar Sekam Padi 25\% + Kotoran Sapi 25\%), P1 (Tanah 50\% + Kotoran Sapi 50\%), P2 (Tanah $50 \%$ + Vermikompos 50\%), dan P4 (Tanah 50\% + Biochar Sekam Padi 25\% + Vermikompos 25\%) menunjukkan bahwa komposisi media tanam tersebut dapat meningkatkan hasil pada tanaman ubi jalar. Beberapa hasil penelitian menunjukkan pengaruh positif dari aplikasi vermikompos dalam meningkatkan hasil beberapa tanaman antara lain jagung manis (Aira et al. 2010), strawberry Singh et al.(2008) dan Lazcano et al. (2009); tanaman sayuran sawi pakcoi, kubis, dan brokoli (Nurhidayati et al., 2015; Nurhidayati et al., 2016; Nurhidayati et al., 2017a; 2017b).

Pengaruh positif ini disebabkan karena vermikompos memiliki pengaruh langsung dan tidak langsung. Pengaruh langsung vermicompost terhadap pertumbuhan tanaman terjadi karena vermicompost menjadi sumber hara makro dan mikro bagi tanaman. Sebagian unsur hara dalam bentuk an-organik yang siap diserap oleh tanaman dan sebagian yang lain dilepaskan secara bertahap melalui proses mineralisasi bahan organik sehingga membentuk suatu pupuk dengan pelepasan lambat yang menyediakan hara secara bertahap bagi tanaman (Lazcano dan Dominguez, 2011; Chaoui et al., 2003). Pengaruh tidak langsung vermicompost terhadap pertumbuhan tanaman ditunjukkan oleh adanya mitigasi atau penekanan serangan penyakit tanaman, dimana beberapa peneliti 
melaporkan bahwa penggunaan pupuk organik sebagai bahan pembenah organik dapat menekan serangan penyakit tanaman (Termorshuizen et al., 2006; Trillas et al., 2006). Vermicompost juga dapat menekan serangan penyakit mikrobia, hama serangga dan nematode parasit bagi tanaman. Pengaruh tidak langsung yang lain adalah melalui perubahan sifat fisik, kimia dan biologi tanah akibat aplikasi vermicomposting. Perbaikan sifat tanah dapat meningkatkan pertumbuhan tanaman (Sutanto, 2002; Lazcano dan Domínguez, 2011).

Penambahan biochar pada perlakuan P3 (Tanah 50\% + Biochar Sekam Padi 25\% + Kotoran Sapi 25\%) dan P4 (Tanah 50\% + Biochar Sekam Padi 25\% + Vermikompos 25\%), diharapkan mampu memperbaiki kondisi fisik, kimia dan biologi media tanam. Biochar digunakan sebagai bahan pembenah tanah untuk memperbaiki sifat-sifat tanah seperti sifat fisik, kimia dan biologi tanah (Gani, 2009). Biochar mampu meningkatkan porositas tanah yang berdampak pada peningkatan kemampuan tanah menahan air dan unsur hara sehingga pertumbuhan tanaman menjadi lebih baik (Downie et al., 2009). Biochar juga memberikan efek positif terhadap sifat kimia tanah yaitu meningkatnya $\mathrm{pH}$ tanah dengan adanya aplikasi biochar (Nurhidayati dan Mariati, 2014) sehingga ketersediaan unsur hara meningkat dan aktivitas mikroorganisme dalam proses dekomposisi bahan organik juga meningkat (Verheijen et al., 2010). Biochar mampu mengendalikan pelepasan $\mathrm{NH}_{4}{ }^{+}$dari pupuk sehingga tidak mudah tercuci (Cai et al., 2016).

Hasil penelitian ini menunjukkan bahwa perlakuan P1 (Tanah 50\% + Kotoran Sapi 50\%) dan P3 (Tanah 50\% + Biochar Sekam Padi 25\% + Kotoran Sapi 25\%). Hasil yang diperoleh menunjukkan tidak berbeda nyata dengan perlakuan yang menggunakan vermikompos. Berbagai hasil penelitian juga telah membuktikan bahwa aplikasi pupuk kotoran hewan memberikan kemungkinan tanaman menimbun bahan kering yang lebih banyak, karena kotoran hewan merupakan pupuk organik yang lepas secara bertahap sehingga dapat memenuhi kebutuhan hara tanaman (Mayadewi, 2007). Pemberian pupuk kandang sapi dengan 30 ton per hektar memberikan pengaruh yang nyata pada pertumbuhan dan hasil umbi bawang merah per hektar (Mayun, 2007). Aplikasi kompos kotoran sapi juga meningkatkan pertumbuhan dan produksi tanaman tomat (Hidayat dan Pangaribuan, 2008). Pupuk kandang sapi merupakan pupuk padat yang banyak mengandung air dan lendir. Pupuk kandang selain dapat menambah ketersediaan unsurunsur hara bagi tanaman, juga mengembangkan kehidupan mikroorganisme di dalam 
tanah. Kotoran ternak sapi merupakan pupuk dingin, yang memiliki kadar hara kotoran padat (feses) yaitu Nitrogen $=0,40 \%$, Fosfor $=0,20 \%$, Kalium $=0,10 \%$, dan Air $85 \%$ sedangkan urine memiliki kadar hara yaitu Nitrogen $=1,00 \%$, Fosfor $=0,50 \%$, Kalium $=$ 1,50\%, dan Air 92\% (Lingga, 2001). Pupuk kandang sapi merupakan pupuk kandang yang berasal dari kotoran sapi yang baik untuk memperbaiki kesuburan, sifat fisika, kimia dan biologi tanah, meningkatkan unsur hara makro dan mikro, meningkatkan daya pegang air dan meningkatkan kapasitas tukar kation (Hadisumitro, 2002).

\section{Hubungan antara Bobot Segar Total Brangkasan dengan Bobot Segar Umbi}

Uji regresi digunakan untuk menentukan hubungan antara bobot segar total brangkasan dengan bobot segar umbi terlihat pada gambar 1. Hasil uji regresi menunjukkan bahwa hubungan antara bobot segar total brangkasan dengan bobot segar umbi mengikuti pola kuadratik yang artinya semakin meningkat bobot segar brangkasan maka bobot segar umbi semakin meningkat sampai titik optimum, melampaui titik optimum akan terjadi penurunan hasil.

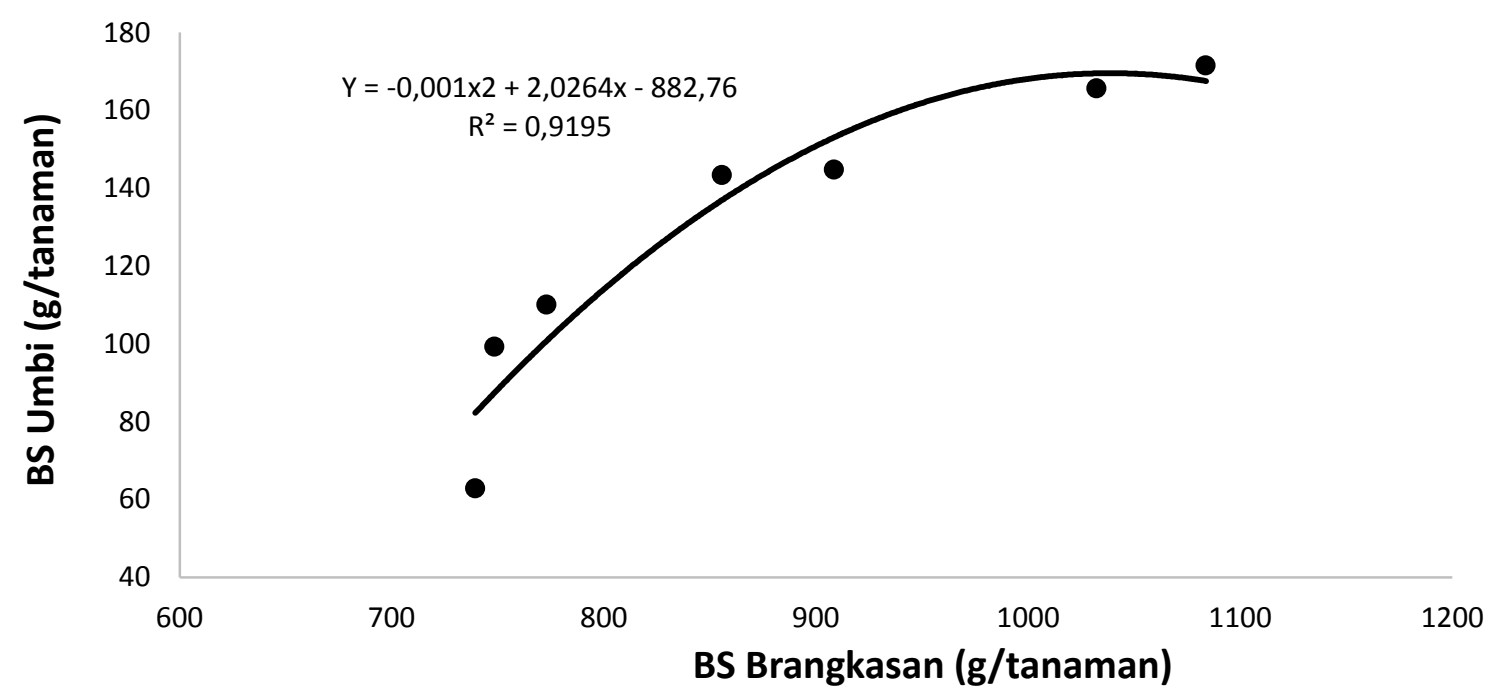

Gambar 1. Hubungan antara Bobot Segar Total Brangkasan dengan Bobot Segar Umbi

Hasil uji regresi diperoleh persamaan regresi $Y=-0,001 X^{2}+2,0264 X-882,76$ dan nilai $R^{2}=0,9195$, diperoleh besarnya bobot segar brangkasan maksimum 1013,20 g dan hasil umbi maksimum 143,81 g. Hal ini sesuai dengan pendapat Sitompul at al (1995) yang mengatakan bahwa tanaman selama masa tertentu memproduksi biomassa yang 
digunakan untuk membentuk bagian-bagian tubuhnya. Produksi biomassa tersebut dapat mengakibatkan peningkatan bobot dan diikuti dengan pertambahan ukuran lainnya secara kuantitatif. Produksi biomassa selama masa vegetatif yang lebih baik, umumnya dapat menentukan hasil tanaman. Apalagi komponen hasil tanaman (bagian ekonomis) dari tanaman ubi jalar adalah bagian generatif yaitu umbi. Namun pertumbuhan vegetatif yang lebih dominan mengakibatkan pertumbuhan bagian atas tanaman (biomassa) meningkat dan mengakibatkan pembentukan umbi menurun (generatif) karena karbohidrat yang tersisa lebih sedikit. Apabila fase vegetatif dan generatif seimbang maka perkembangan umbi menjadi optimal (Harjadi, 1996).

\section{Kesimpulan dan Saran}

Berdasarkan hasil penelitian ini dapat disimpulkan bahwa perlakuan pengaturan komposisi media tanam organik berpengaruh nyata terhadap pertumbuhan dan hasil tanaman ubi jalar. Secara umum perlakuan P4 (Tanah 50\% + Biochar Sekam Padi 25\% + Vermikompos 25\%) dan P6 (Tanah 50\% + Cocopeat 25\% + Vermikompos 25\%) mewakili pertumbuhan tanaman yang tertinggi, sedangkan perlakuan P3 (Tanah 50\% + Biochar Sekam Padi 25\% + Kotoran Sapi 25\%), P1 (Tanah 50\% + Kotoran Sapi 50\%), P2 (Tanah $50 \%$ + Vermikompos 50\%), dan P4 (Tanah 50\% + Biochar Sekam Padi 25\% + Vermikompos 25\%) memberikan bobot hasil ubi jalar yang tinggi. Perlakuan P3 (Tanah $50 \%$ + Biochar Sekam Padi 25\% + Kotoran Sapi 25\%), P1 (Tanah 50\% + Kotoran Sapi 50\%), P2 (Tanah 50\% + Vermikompos 50\%), dan P4 (Tanah 50\% + Biochar Sekam Padi $25 \%$ + Vermikompos 25\%) memberikan kandungan bahan kering umbi yang tinggi. Berdasarkan hasil penelitian ini disarankan bahwa untuk budidaya ubi-ubian dalam pot dibutuhkan media tanam yang porus seperti biochar sekam padi dan pupuk organik padat (kotoran hewan dan vermikompos), namun harus tersedia unsur hara yang seimbang untuk mendapatkan umbi yang maksimal.

\section{Ucapan Terimakasih}

Peneliti mengucapkan terima kasih kepada PT Indofood Sukses Makmur,Tbk. yang telah memberikan dana penelitian melalui program Indofood Riset Nugraha $2019 / 2020$. 


\section{Daftar Pustaka}

Aira, M., M. Gómez-Brandón, C Lazcano, E. Baath, and J. Domínguez. 2010. Plant genotype strongly modifies the structure and growth of maize rhizosphere microbial communities. Soil Biology and Biochemistry, 42 (12): 2276-2281.

Anonim, 2013, Pengaruh berbagai media terhadap perkecambahan matoa. Skripsi. http://respiratory.ipb.ac.id/handle/, diakses tanggal 15 Januari 2020.

Badan Pusat Statistik Republik Indonesia. 2015. Produksi Ubi Jalar Indonesia. https://www.bps.go.id/linkTableDinamis/view/id/883[10 Juli 2019].

Chaoui H.I., L.M. Zibilske, and T. Ohno. 2003. Effects of earthworm casts and compost on soil microbial activity and plant nutrient availability. Soil Biol.Biochem. 35: 2295-302.

Downie, A.; A., Crosky; P, Munroe. 2009. Physical Properties of Biochar. In: Lehmann, J.; Joseph, S (ed.). Biochar for enviromental management: Science and Technology. 1. Londres: Earthscan, 2009. 416p.

Fatahillah. 2017. Uji penambahan berbagai dosis vermikompos cacing (Lumbricus Rubellus) terhadap pertumbuhan vegetatif cabai rawit (Capsicum frutescens L.). Biotek. 5(2): 191-204.

Gani, A. 2009. Potensi arang hayati "Biochar" sebagai komponen teknologi perbaikan produktivitas lahan pertanian. Iptek Tanaman Pangan. 4(1): 33-48.

Hadisumitro, L. M. 2002. Membuat Kompos. Jakarta : Penebar Swadaya, 54 hal.

Hadiwiyono dan W.S. Dewi. 2000. Uji pengaruh penggunaan vermikompos, Trichoderma viridedan, mikoriza vesikula arbuskula terhadap serangan cendawan akar bengkak (Plasmodiophora brassicaeWor.) dan pertumbuhan pada caisin. Caraka Tani. 15 (2): hal 20-28.

Harsono, S.S., P. Grundman, L.H. Lau, A. Hansen, M.A.M. Saleh, A. M. Aurich, A. Idris and T.I.M Gazi. 2013. Energy balances, greenhouse gas emissions and palm oil empty fruit bunches. Resources Conservation and Recycling, 77 : 108-115

HarjadiS.S. (1996). Pengantar agronomi. Jakarta:PT.Gramedia Pustaka Utama.

Hidayat, P. dan D. Pangaribuan. 2008. Pengaruh dosis kompos pupuk kandang sapi Terhadap Pertumbuhan Dan Produksi Buah Tomat. Prosiding Seminar Nasional Sains dan Teknologi-II 2008 Universitas Lampung, 17-18 November 2008.

Lazcano, C. and J. Dominguez. 2011. The use of vermicompost in sustainable agriculture : impact on plant growth and soil fertility. In : Soil Nutrients. Miransari, M. (Ed). ISBN : 978-1-61324-785-3. Nova Sience Publishers, Inc. p 1-23.

Lingga, P.M. 2001. Petunjuk penggunan pupuk. Penebar Swadaya. Jakarta. 154 Hal.

Mayadewi, N.A.. 2007. Pengaruh Jenis pupuk kandang dan jarak tanam terhadap pertumbuhan gulma dan hasil jagung manis. Agritrop. 26 (4) : 153 - 159.

Mayun, I. A. 2007. Efek mulsa jerami padi dan pupuk kandang sapi terhadap pertumbuhan dan hasil bawang merah di daerah pesisir. Agritrop. 26 (1) : $33-40$. 
Nurhidayati, U. Ali, and I. Murwani. 2016. Yield and quality of cabbage (Brassica oleraceaL.var. Capitata) under organic growing media using vermicompost and earthworm Pontoscolex corethrurus inoculation. Agriculture and Agriculture Science Procedia. 11: 5-13.

Nurhidayati and Mariati. 2014. Utilization of maize cob biochar and rice husk charcoal as soil amendments for improving acid soil fertility and productivity. Journal of Degraded and Mining Lands Management 2 (1) : 223-230.

Nurhidayati, Ali U, Murwani I. 2015. Influence of the kind of vermicompost material and earthworm Pontoscolex corethrurus population on the yield and quality of phak-coi mustard (Brassica rapa L.) with organic potting media. In: Proceeding of the first international conference on life science and biotechnology exploration and conservation of biodiversity. ISBN: 978-602-9030-98-3.p.168-176.

Nurhidayati, M. Machfudz, dan I. Murwani. 2017. Pertumbuhan, hasil dan kualitas tanaman brokoli (Brassicace Oleraceae I.) sebagai respon terhadap aplikasi tiga macam vermikompos dengan 22rgani penanaman secara 22rganic. Prosiding Seminar Nasional Fakultas Pertanian 2017. Fakultas Pertanian Universitas Nasional. ISBN : 978-602-61781-0-7.

Risnandar, C.2012. Jenis dan karakteristik pupuk kandang. Diakses dari : http ://alamtani.com/pupuk-kandang. Diakses pada tanggal : 1 Juli 2019

Saputro, R. R., Purwanti, S dan Rogomulyo, R.2012. Pengaruh Takaran Pupuk Kascing 32 (Glycine $\operatorname{maxx}($ L.) Merill). Skripsi.Fakultas Pertanian, Universitas Gajah Mada

Sato, S.S and H. Mori. 2001. Control Outgrowth and Dormancy In Axilary Bud.

Singh, K., B.S. Bhimawat, and N.K. Punjabi., 2008. Adaption of vermiculture technology by tribal farmers in Udaipur District of Rajasthan. International of Rural Studies. 15(1):1-3.

Sitompul S.M. \& Guritno B.(1995). Analisis Pertumbuhan Tanaman. Yogyakarta: Gadjah Mada University Press.

Sutanto, R. 2002. Penerapan Pertanian Organik.Kanisius. Yogyakarta. 219 hlm.

Termorshuizen, A.J., E, van Rijn., D.J, van der Gaag., C, Alabouvette., Y, Chen., J, Lagerlöf., A.A, Malandrakis., E.J, Paplomatas., B, Rämert., J, Ryckeboer., C, Steinberg. and S, Zmora-Nahum. 2006. Supressiveness of 18 composts against 7 pathosystems: Variability in pathogen response. Soil Biology and Biochemistry 38:2461-2477.

Trillas M.I., E, Casanova., L, Cotxarrera., J, Ordovás., C, Borrero. and M, Avilés. 2006. Composts from agricultural waste and the Trichoderma asperellum strain T-34 suppress Rhizoctonia solani in cucumber seedlings. Biological Control 39:32-38.

Verheijen, F.; S, Jeffery, S.; A.C, Bastos.; M, Velde. van der; I, Diafas.2010. Biochar application to soils: a critical scientific review of effects on soil properties, processes and functions. Luxembourg: European Commission. Vol ():149pp. 